Gisela Syaputri Ayu Geby, Postgraduate Student, Faculty of Economy, Sriwijaya University, Palembang,

ORCID ID: 0000-0002-4897-8337

e-mail: ayugeby34@gmail.com

Susetyo Didik, Professor, Doctor (Economics), Lecturer at the Faculty of Economy, Sriwijaya University, Palembang, Indonesia

ORCID ID: 0000-0002-2435-3519

e-mail: didiksusetyo@yahoo.com Indonesia

Sukanto, Doctor (Economics), Lecturer at the Faculty of Economy, Sriwijaya University, Palembang,

ORCID ID: 0000-0002-1946-3270

e-mail: soekanto0813@gmail.com

\title{
Balance between Budget and Fiscal Policy: Empirical Evidence in South Sumatra Province
}

Abstract. Introduction. Current budget balance is one problem encountered by the government which aims are to make a country/region prosperous, fiscal policy is one of the government's efforts to regulate budget balance. In the case of balance budget and personnel expenditure, many governments have not been able to implement fiscal policies properly so that budget imbalances often occur. This research was conducted to determine how the balance of the budget and its relationship with fiscal policy in South Sumatra Province cause in each district/city has a unique area so that inequality often occurs. The data used in this study are secondary data from the Central Bureau of Statistics and the Directorate General of Taxes and Finance. The data analysis method which was seduced was panel data regression. The results of this study are expected to be a reference material for further research and government considerations in planning budget expenditures in South Sumatra Province.

Purpose. This study analyzes fiscal expenditure which includes balance funds and personnel expenditure and economic growth in budget balance in South Sumatra Province in 2009 - 2018.

Results. The results of this study indicate that (1) the balance funds and personnel expenditure have a positive effect on budget imbalances in the Regency/City of South Sumatra Province, but the effect of the balance funds is not significant, (2) economic growth has a negative and significant effect on budget imbalances in South Sumatra Province.

Conclusion. Based on the regression results of the balance fund variable, personnel expenditure and economic growth are the determining variables for the balance of the budget in South Sumatra Province because it is seen from the R Square value of 72.8 percent and the greatest influence of fiscal policy in determining the balance of a budget is personnel expenditure. The implications of the research results can be a strategy to regulate the balance of the budget in each district/city South Sumatra Province. In addition, by regulating sound fiscal policy by the government, we hope it can reduce the budget deficit and create budget balance.

Keywords: budget balance; fiscal sustainability; budget deficit; budget surplus

\section{Удк 336.02}

Гізела Сяпутрі Аю Гебі, аспірант, факультет економіки, Університет Шрівіджая, Палембанг, Індонезія

Сусетьо Дідік, професор, доктор економічних наук, викладач факультету економіки, Університет Шрівіджая, Палембанг, Індонезія

Суканто, доктор економічних наук, викладач факультету економіки, Університет Шрівіджая, Палембанг, Індонезія

\section{Баланс між бюджетною та фіскальною політикою: емпіричні дані в провінції Південна Суматра}

Анотація. Поточний баланс бюджету - одна з проблем уряду, який прагне зробити крайну/регіон успішними, а фіскальна політика - один із напрямів діяльності уряду щодо регулювання бюджетного балансу. В умовах збалансованості бюджету та витрат на персонал багато урядів не змогли належним чином реалізувати фіскальну політику, тому часто виникали дисбаланси бюджету. Дане дослідження було проведено з метою уточнення, як збалансованість бюджету та його взаємозв'язок із фіскальною політикою в провінції Південна Суматра впливають на те, що кожен район/місто мають унікальну територію, однак часто у них виникає нерівність. Дані, використані у дослідженні, є вторинними даними Центрального бюро статистики та Головного управління податків і фінансів. Серед методів аналізу даних було використано регресію панельних даних. Очікується, що результати цього 
дослідження стануть довідковим матеріалом для подальших досліджень та будуть використані урядом при плануванні бюджетних видатків у провінції Південна Суматра.

У дослідженні проаналізовано бюджетні витрати, які включають балансові фонди і витрати на персонал, а також економічне зростання у бюджеті провінції Південна Суматра у 2009-2018 роках.

Результати дослідження вказують на те, що: балансові фонди та витрати на персонал позитивно впливають на бюджетні дисбаланси в регіоні Південна Суматра, однак ефект балансових фондів не $\epsilon$ значним; економічне зростання має негативний та значний вплив на бюджетні дисбаланси в провінції Південна Суматра.

Таким чином, на підставі результатів регресії змінної фонду балансу, витрат на персонал та економічного зростання можна зробити висновок, що вони є визначальними змінними для балансу бюджету в провінції Південна Суматра. Про це свідчить значення показника R2 72,8 відсотка. Найбільший вплив фіскальної політики на баланс бюджету мають витрати на персонал. Враховуючи дані результати дослідження, має бути розроблена стратегія регулювання балансу бюджету в кожному районі/місті Південної Суматри. Крім того, здійснюючи виважену фіскальну політику, уряд зможе зменшити дефіцит бюджету та забезпечити збалансованість бюджету.

Ключові слова: бюджетний баланс; фіскальна стійкість; дефіцит бюджету; профіцит бюджету.

Formulation of the problem. Current budget balance is one problem encountered by the government which has aims to make a country / region prosperous, one of the government's efforts to regulate budget balance is by regulating its fiscal policies [1].

South Sumatra Province in each district / city has a unique area so that inequality often occurs in the districts / cities of this province [2]. The highest component of government spending is in South Sumatra Province based on annual data Anggaran Pendapatan dan Belanja Daerah (2020) is personnel expenditure, where the allocation reaches 9.4 trillion or $66 \%$ of other regional expenditure components where each year personnel expenditure has increased.

According to Sudarso (2018) the cause of the high expenditure for employees in each Regency / City of South Sumatra Province is due the payment of allowance ied fitri (THR) for State Civil Apparatus (ASN) employees and non State Civil Apparatus (ASN) employees because of the payment of allowance ied fitri (THR) received from year to year is the full value of the employee salary without piece. The high increase in personnel spending has been proven by the annual government work plan quoted from the website Kementerian Keuangan Republik Indonesia (2017) which states that an increase in the salary of honorary government employees is equivalent to the salary of permanent employees and the increase in the number of employees increases from year to year so in this case, personnel expenditure is fixed expenditure, according to Sudarso (2018) It is likely that the number of permanent employees or State Civil Apparatus (ASN) cannot be reduced because the government cannot reduce the number of ASNs through the work termination (PHK) mechanism as is done by private parties. The number of civil servants will be reduced by the pension mechanism.

According to UU nomor 33 tahun 2014 one component to reduce the amount of personnel expenditure is regulated by the balance fund, so personnel expenditure is also regulated by the balance fund, if the balance fund is properly regulated by looking at the components of income and expenditure, it can create a budget balance [1].

Economic growth has a relationship with fiscal policy if the economic growth of a region is positive, showing that the fiscal expenditure made by the regional government has been successful so that in this case it creates a budget balance [7].

A budget deficit or surplus is the difference in comparison between government revenue and its expenditures, a budget deficit can occur if the government spends more than its revenue so that a budget surplus can occur if the level of revenue exceeds the level of expenditure [8].

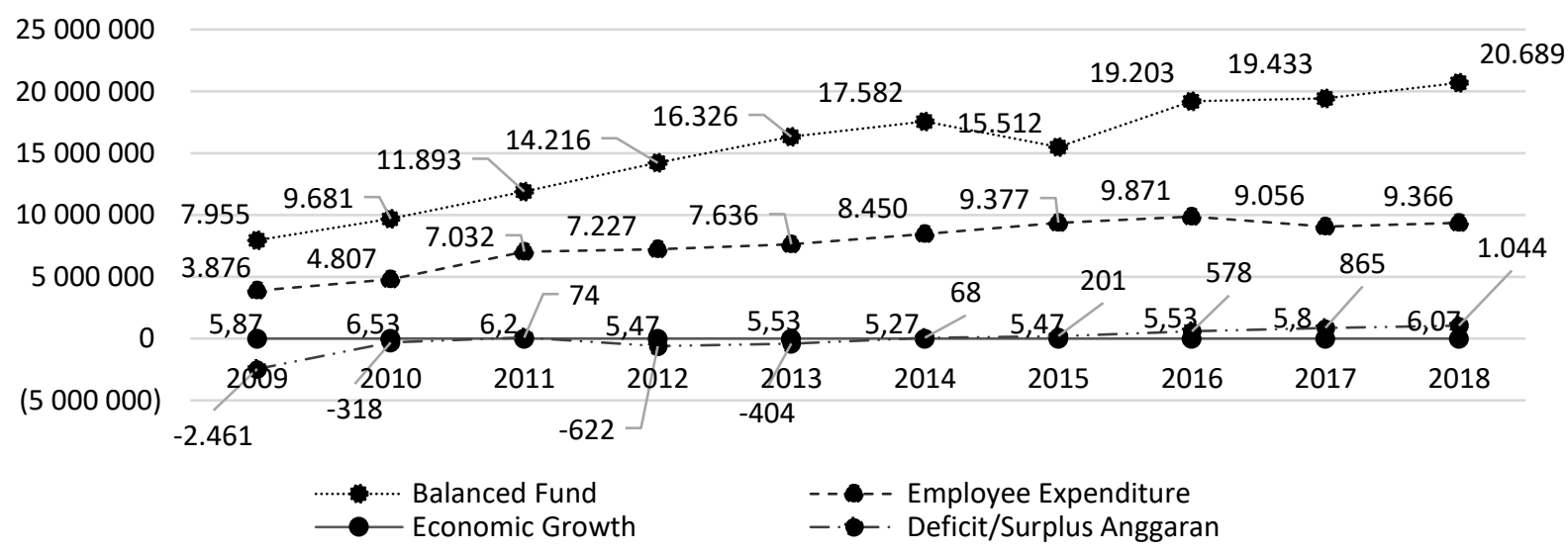

Figure 1 - Development of Balancing Funds, Personnel Expenditures, and Economic Growth to the Budget Balances in South Sumatera Province in 2009-2018

Source: Directorate General of Tax and Finance and the Central Statistics Agency of South Sumatra Province, June 2020 
This condition can occur in South Sumatra Province, following the trend of balancing funds, personnel expenditure, and economic growth on the budget deficit / surplus during 2009-2018.

In general, described in Figure 1 shows overall the relationship between all independent variables and the dependent variable in South Sumatra has an on average disproportionate relationship, for example, in 2014-2018 period, South Sumatra Province experienced a budget surplus, but in terms of fiscal expenditure experienced an increase as well as economic growth. This condition shows that there is a budget surplus conditions, all this also shows that there is an imbalance between implementing fiscal policy and the balance of the budget. Conditions that the budget surplus is achieved when there are conditions of budget balance, this problem indicates that there is a long-term relationship between fiscal spending and budget balance [9] and according to Ocran (2011) fiscal policy has varying effects on output, but the effect of fiscal policy on budget input is relatively low but still exists; however, the response is temporary and substantial in most cases, for example according to Narayan \& Narayan (2006) if there is an increase in government spending, especially in a fiscal context, it will have a significant impact on reducing the balance of the budget. So in this problem the government need to make limit the fiscal budget, especially personnel expenditure [12] and according to Khairani (2017) transfer funds have an enormous influence on the balance of the budget.

Based on the results of the data, economic growth has an unbalanced relationship in the long run. The occurrence of budget imbalances caused by economic growth has many factors, one of which is the high level of government spending and revenue which is not followed by a high rate of economic growth, this problem is based by research Todorova (2019) which states that an increase economic growth must be based on the level of spending and income, and according to Ahmad \& Rahman (2017) GDP is proven to reduce budget deficit. Research Dao (2014) who found that Economic Growth and Budget Balance did not have a causal relationship, according to him that budget restrictions were needed in achieving budget balance and fiscal sustainability. Fiscal sustainability is discussed Bui (2019) which reveals that fiscal sustainability in the long term is determined by economic conditions, especially sustainable economic growth.

Analysis of recent research and publications. Siebel \& Pitsoulis (2011) explain the balanced budget theory which states that the level of government spending must be balanced with the level of revenue generated by the government so that there is no budget deficit, meaning that in this theory there is no budget deficit or it is balanced budget. Furthermore, it is explained about the government budget theory which describes the fiscal strategy issued by the government to regulate a budget, in line with the deficit strategy in this theory the government tries to influence people's behavior in using the budget in line with direct and indirect expenditure financing, the government does not spend all of it. The budget is for social security and infrastructure but eliminates the difference as additional rent, in this case also according to this theory the government's efforts improve economic conditions by adjusting the conceptual tax rate balance if GDP / GRDP (which is a benchmark for economic growth) increases, it will impact an increase in economic activity, mainly the real sector and the business world so an increase in economic activity will influence increasing government revenue through taxation because economy so that the activity of the business world increases and corporate profits increase. Increasing the activities and profits of these companies will certainly increase taxation both from income tax, value added tax, and excise [18].Tax revenue is the key thing for domestic revenue with an increase in tax revenue, which will result in a decrease in the APBN / APBD deficit [19].

In line with this, many studies discuss budget balance and the factors that influence it, among others, according to Anggreni \& Sri (2018) the allocation of government expenditures contained in the balance fund component has a positive effect on the occurrence of a budget deficit, it means that in this case a budget surplus can occur if the balance funds are of low value. According to Priatiningsih et al., (2013) Personnel expenditure has a positive effect which can lead to a budget deficit, meaning that in this case a budget surplus can occur when personnel expenditure is low. According to Amalia (2019), Fatima et al., (2012), Oltjana Zoto \& Berisha Msc (2016), Eka et al., (2019), Satrianto (2015), and Ramadhani (2014) economic growth has a negative effect on the budget deficit but this is contrary to research Nwanne (2014), Nwakobi et al., (2018), Arjomand et al. (2016) Nkechi \& Gabriel (2017) and Molocwa et al. (2018) which states that economic growth has a positive effect on the budget deficit. Here, the positive effect of economic growth on the budget deficit is because a country / region implements a fiscal deficit policy where the government always overcomes an economy whose economic growth is experiencing sluggishness by increasing its expenditure which is higher than revenue it is resulted in a country / region experiencing shortages of the budget [32]. Meanwhile, for the negative effect, the government applies a balance of tax rates under the theory of the government budget [18].

Formulation of research goals. The purpose of this research is to analyze fiscal expenditures which include balance funds and personnel expenditures and economic growth on budget balance in South Sumatra Province.

Outline of the main research material. This research consists of three independent variables and one dependent variable, where the balance fund, personnel expenditure, and economic growth are independent variables and the budget deficit / surplus is the dependent variable. The analysis used in this research is quantitative analysis where all the variables are regressed first and then a qualitative analysis is carried out, namely where after regression, data analysis is carried out. The type of 
data in this study is secondary data where the publication of this data is taken from the official website, namely the Directorate General of Tax and Finance (DJPK), and the Central Statistics Agency (BPS) for the 2009-2018 period. The method of analysis used in this research is panel data regression analysis, the goal is to see how the significant effect of fiscal policy on budget balance in each District / City Province in South Sumatra. The analysis model made in this study is as follows:

BFit $=\alpha+\beta 1$ BFit $+\beta 2$ PEit $+\beta 3$ EGit
BB - Budget Balance or budget deficit/surplus;

BF - Balanced Fund;

PE - Personnel expenditure;

EG - Economic growth;

I - Individual;

$\mathrm{t}$ - time.

$\beta 1 \beta 2 \beta 3$ : Coefficient for each related variable in research

Based on the results of the theory review above can made the mindset as follows:

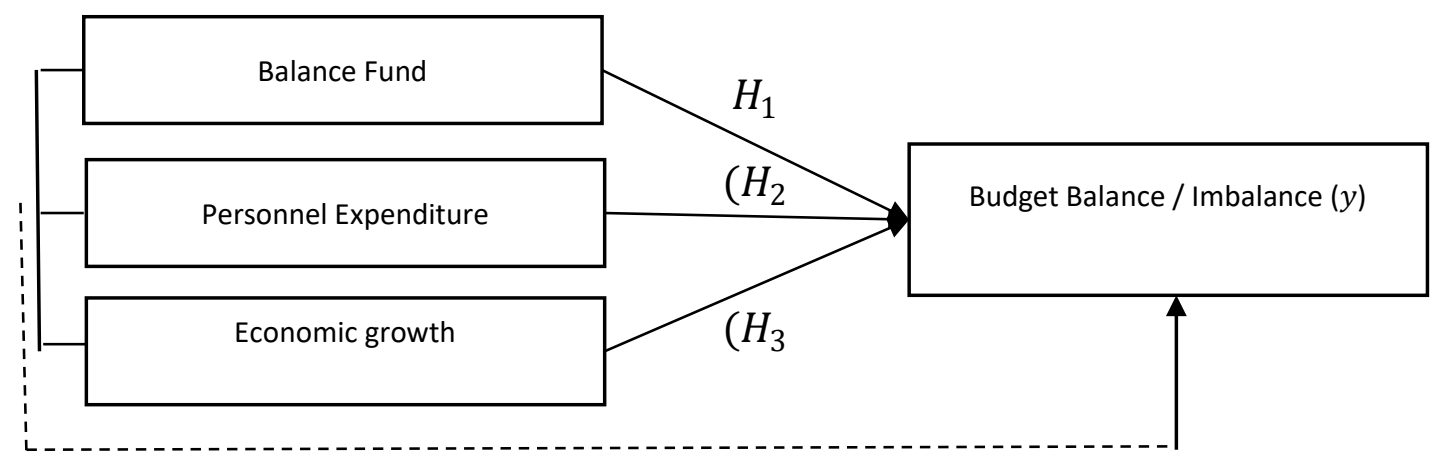

Figure 2-Conceptual Framework

Source: author's calculations.

Figure 2 shows the theoretical framework analyzed to see the relationship between balanced funds, personnel expenditure and economic growth (fiscal policy) to budget balance / imbalance in South Sumatra Province in 20092018, as for the hypothesis that can be written based on the results of theoretical analysis as follows:

1. Balanced funds have a positive effect on the budget imbalance
2. Personnel expenditure have a positive effect on the budget imbalance

3. Economic growth has a negative effect on the budget imbalance

Based on the results of the model test, namely the Chow and Hausman test, the most suitable model for panel data regression in this study is the fixed effect model.

Table 1 Model Summary Panel Data Regression Output Result

\begin{tabular}{|c|c|c|c|c|}
\hline Variable & Coefficient & Std. Error & t-Statistic & Prob. \\
\hline C & -310237.3 & 91930.16 & -3.374706 & 0.0010 \\
\hline DP? & 0.074788 & 0.052744 & 1.417943 & 0.1593 \\
\hline BP? & 0.311877 & 0.136607 & 2.283023 & 0.0245 \\
\hline PE? & -13.18695 & 7651,524 & -1.723441 & 0.0478 \\
\hline R-squared & 0.728070 & \multicolumn{2}{|c|}{ Mean dependent var } & 13360.73 \\
\hline Adjusted R-squared & 0.699414 & SD dependent var & 100235.0 \\
\hline SE of regression & 95122.20 & Sum squared reside & 26.31932 \\
\hline F-statistic & 1.772721 & Durbin-Watson stat & 2.401758 \\
\hline Prob (F-statistic) & 0.041822 & \multicolumn{2}{l}{} \\
\hline
\end{tabular}

Source: Data Processed, 2020

Based on the results of the regression analysis above, it shows that the variable balance funds and personnel expenditure are positive and the economic growth variable is negative, in this case the regression results above can be made the following equation:

$$
\begin{gathered}
K A=-310237.3+0.074788 D P+0.311877 B P- \\
13.18695 P E
\end{gathered}
$$

Based on the value of the coefficient of determination (R2) shows that the value of the coefficient of determination is 0.728 or 72.8 percent, which means that 72.8 percent of the variables of balanced funds, personnel expenditure, and economic growth are able to explain the remaining budget balance variable (27.2 percent) explained by the other variable was not included in the regression model.

Due to the results the regression model estimation shows that the probability value of balanced funds is 0.1593 or a value $>0.05$ means that the balanced fund variable has a positive but insignificant effect on budget 
balance, based on the analysis of the government budget theory analysis and research by Anggreni \& Sri (2018) it means the positive effect of balancing funds can cause a budget deficit. The regression coefficient of the balance funds is 0.074788 , meaning that if there is an increase in the balance funds by $1 \%$, it will increase the budget deficit by 0.074788 percent.

Our results which are based on the regression model estimation shows that the probability value personnel expenditure of 0.0245 or the value $<0.05$ means that the personnel expenditure variable has a positive and significant effect on budget balance based on the analysis of the theory the government budget study and research by Prihatiningsih et al. (2013) means that the positive effect of personnel spending can lead to a budget deficit. The regression coefficient for personnel expenditure is 0.311877 , all this means that if there is an increase in personnel expenditure by $1 \%$, it will increase the budget deficit by 0.311877 percent.

Based on the results of the regression model estimation shows that the probability value economic growth of 0.0478 or a value $<0.05$ means that the economic growth variable has a negative and significant effect on the budget deficit based on the analysis of the theory the government budget study and research. Amalia (2019), Fatima et al. (2012), Oltjana Zoto \& Berisha Msc (2016), Eka et al. (2019), Satrianto (2015), and Ramadhani (2014) This means that the negative effect of economic growth can cause a budget surplus where the regression coefficient of economic growth is $-13,18695$, meaning that if there is an increase in economic growth of $1 \%$ it will reduce the budget deficit by $-13,18695$ percent and vice versa.

The $\mathrm{F}$ statistical probability value is $0.041822<0.05$, which indicates that the variables of balanced funds, personnel expenditure, and economic growth collectively have a significant effect on budget balance.

Balanced funds have a positive but insignificant effect on budget balance, or based on government budget theory and research by Anggreni \& Sri (2018) an increase in balanced funds can cause budget deficits. This means that an increase in balancing funds will not significantly affect the increase in the budget deficit. The insignificance of the balanced fund variable is in line with the government budget theory which states that in expenditure management in the direct and indirect expenditure components the government does not spend all its budget but eliminates the difference as additional rent, so in this case the high and low budget deficit is reflected by the balance funds so we can see it from how the government manages its expenditures as best as possible the allocation of government expenditure balanced funds to be carried out [18]. This result is in line with research of Anggreni \& Sri (2018) states government expenditures in the balance fund component have a positive effect on implementing the budget deficit.
Personnel expenditure has a positive and significant effect on the variable budget balance. Results of the government budget theory analysis and research Priatiningsih et al., (2013) the positive effect of personnel expenditure can lead to a budget deficit. In general, this means that any significant increase in personnel expenditure will affect the increase in the budget deficit. All this occurs personnel expenditure is a component of government expenditure and if government expenditure is higher than revenue it can cause a budget deficit [8]. So in this case, the more personnel expenditure the government releases, it will encourage a budget deficit. These results are in line with the research by Priatiningsih et al., (2013) states that personnel expenditure has a positive effect which can lead to a budget deficit.

Economic growth has a negative and significant effect on budget balance. In general, due to the results analysis of the theory of the government budget, this condition shows that an important increase in economic growth will reduce the budget deficit and according to this theory, an increase in economic growth based on government revenue through tax revenue can reduce the budget deficit [21].These results are in line with research by Amalia (2019), Fatima et al., (2012), Oltjana Zoto \& Berisha Msc (2016), Eka et al., (2019), Satrianto (2015), and Ramadhani (2014) states that economic growth has a negative effect on the budget deficit, in this case it means the economic conditions in South Sumatra Province to reduce the budget deficit by applying a balance tax rate.

The positive effect of balancing funds and personnel expenditures when linked to balanced budget theory that is, government spending must be balanced with the level of income so there will be no budget deficit [18]. However, the results of this study state that on the contrary, government spending is not balanced, causing a budget deficit.

Conclusions. The results of analysis and testing, carried by showed the researchers showed that balanced funds and personnel expenditures have a positive effect on imbalance budget, or in other words, the positive effect of balanced funds and personnel expenditures can cause budget deficit, but statistically balanced funds do not have a significant effect and personnel expenditure is statistically significant. Meanwhile, economic growth has a negative and significant effect on imbalance budget, or the negative effect of economic growth can reduce the budget deficit. Based on the calculation of the value of R2 0.728070 or 72.8 percent the balance fund, personnel expenditure, and economic growth are the determining factors for budget balance in South Sumatera Province and this situation is acceptable for the government of South Sumatra Province to establish a budget policy to create a prosperous economy and not cause regional debt, in other words a budget deficit. 
Електронне наукове фахове видання з економічних наук “Modern Economics», №23 (2020), 44-49 https://modecon.mnau.edu.ua | ISSN 2521-6392

\section{References:}

1. Saretta, I. R. (2019). Kebijakan Fiskal : Salah Satu Strategi Pemerintah Mengatasi Masalah Internal Negara.

2. Badan Pusat Statistik Indonesia, Statistik indonesia 2019. Retrieved from www.bps.go.id.

3. Kementerian Keuangan (2020). Anggaran Pendapatan Belanja Daearah. Retrieved from djpk.kemenkeu.go.id.

4. Sudarso (2018). Pembayaran Tunjangan Hari Raya (THR) Aparatur Negeri Sipil (ASN) sebesar Take Home Pay (THP) menjadi faktor utama kenaikan belanja pegawai yang bersumber dari APBN 2018 di Sumatra Selatan (Sumsel). Retrieved from https://sumatra.bisnis.com/read/20180710/533/814829/belanja-pegawai-di-sumsel-melonjak-karena-thr.

5. Kementerian Keuangan Republik Indonesia. Badan Kebijakan Fiskal Kementerian Keuangan Republik Indonesia 2017.

6. UU nomor 33 tahun (2014). UU 33 tahun 2014 tentang Perimbangan Keuangan antara Pemerintah dan Pemerintahan Daerah.

7. Tung, L. T. (2018). The effect of fiscal deficit on economic growth in an emerging economy: Evidence from Vietnam. J. Int. Stud., 11(3), 191-203. doi: 10.14254/2071-8330.2018/11-3/16.

8. Molocwa, G. A., Khamfula, Y. \& Cheteni, P. (2018). Budget deficits, investment and economic growth: A panel cointegration approach. Invest. Manag. Financ. Innov., 15(3), 182-189. doi: 10.21511/imfi.15(3).2018.15.

9. Gounder, A. Neelesh, Narayan, Paresh Kumar, Prasad (2007). An empirical investigation of the relationship between government revenue and expenditure: The case of the Fiji Islands. Int. J. Soc. Econ., 34(3), 147-158. doi: 10.1108/03068290710726711.

10. Ocran, M. K. (2011). Fiscal policy and economic growth in South Africa. J. Econ. Stud., 38(5), 604-618. doi: 10.1108/01443581111161841.

11. Narayan, P. K. and Narayan, S. (2006). Government Revenue and Government Expenditure nexus: Evidence from developing countries. Appl. Econ., 38(3), 285-291. doi: 10.1080/00036840500369209.

12. Costello, A. M. Petacchi, R. and Weber, J. P. (2017). The impact of balanced budget restrictions on states' fiscal actions. Account. Rev., 92(1), 51-71. doi: 10.2308/accr-51521.

13. Khairani, A. (2017). Pengaruh Pendapatan Asli Daerah dan Dana Transfer terhadap Defisit Anggaran pada Kabupaten dan Kota di Sumatera Selatan. Politeknik Negeri Sriwijaya.

14. Todorova, T. (2019). Government Budget Balance And Economic Growth. J. Int. Sci. Publ., 13 (9), 1689-1699.

15. Ahmad, F. and Rahman, B. (2017). The Relationship between Budget Deficit and Economic Growth : A Study on Bangladesh. ASA Univ. Rev., 11(2), 1-13.

16. Dao, B. T. (2014). The Relationship between Budget Deficit and Economic Growth in Vietnam. SSRN Electron. J., 5(11), 79-85. doi: $10.2139 /$ ssrn.2514134.

17. Bui, D.-T. (2019). Fiscal sustainability in developing Asia - new evidence from panel correlated common effect model. J. Asian Bus. Econ. Stud., 27(1), 66-80. doi: 10.1108/jabes-01-2019-0001.

18. Siebel, J. P. and Pitsoulis, A. (2011). Four budget deficit theories in one model. J. Econ. Educ., 11(1), 25-32.

19. Kunarjo. Defisit Anggaran Negara. Retrieved from www.bappenas.go.id.

20. Anggreni, N. K. A. and Artini, L. G. Sri (2018). Pengaruh PAD, Dana Perimbangan Dan Belanja Modal Terhadap Kinerja Keuangan Daerah Kabupaten Badung Provinsi Bali. E-Jurnal Manaj. Univ. Udayana, 8(3), 1315. doi: 10.24843/ejmunud.2019.v08.i03.p06.

21. Astuti Prihatiningsih, M. R. R, and S. HM (2013). Defisit Anggaran dan Implikasinya terhadap Perkembangan Ekonomi dan Kinerja Keuangan Kabupaten Tebo. J. Fak. Ekon. Univ. Jambi, 1(2), 97-108.

22. Amalia, N. H. S. (2019). Pengaruh Inflasi, Pertumbuhan Ekonomi, Terhadap Defisit Anggaran Indonesia. E-Jurnal Univ. Jambi, 6(2).

23. Fatima, G. Ahmed, M. and Rehman, W. ur (2012). Consequential Effects of Budget Deficit on Economic Growth of Pakistan. Int. J. Econ. Financ., 5(3), 203-208. doi: 10.5539/ijef.v5n3p90.

24. Oltjana Zoto A. and Berisha. M. (2016). Budget Deficit and Economic Growth in Albania. Int. J. Eng. Sci. Res. Technol., 5(9), 333-340. doi: 10.5281/zenodo.154199.

25. Eka, H. Maruto, P. and Basuki, U. (2019). Analisis Pengaruh Investasi dan Budget Deficit Terhadap Pertumbuhan Di Indonesia. Diponegoro J. Econ., 1, 67. Retrieved from https://ejournal2.undip.ac.id/index.php/dje.

26. Satrianto, A. (2015). Analisis Determinan Defisit Anggaran dan Utang Luar Negeri di Indonesia. J. Kaji. Ekon., 4(7), 103736.

27. Ramadhani, M. A. (2014). Pengaruh Defisit Anggaran, Pengeluaran Pemerintah Dan Hutang Luar Negeri Terhadap Pertumbuhan Ekonomi (Studi Kasus 6 Negara Asean Tahun 2003-2012). J. IIm.

28. Nwanne, H. Dr. (2014). Impact of Budget Deficit Financing on Economic Stability in Nigeria. Dep. Accounting/Finance, Manag. Soc. Sci. Godfrey Okoye Univ. Enugu Fac., 2(8), 122-135.

29. Nwakobi, P. C. Echekoba, F. N. and Ananwude, A. C. (2018). Fiscal Deficit in an Oil Dependent Revenue Country and Selected Macroeconomic Variables: a time series analysis from Nigeria (1981-2015). Eur. J. Econ. Financ. Res., 3(1), 126-167. doi: 10.5281/zenodo.1285257.

30. Arjomand, M. Emami, K. and Salimi, F. (2016). Growth and Productivity; The Role of Budget Deficit in the MENA Selected Countries. Procedia Econ. Financ., 36(16), 345-352. doi: 10.1016/s2212-5671(16)30046-6.

31. Nkechi, F. and Gabriel, A. (2017). Assessment of Impact of Government Budget Deficits on Unemployment Rate in Nigeria, 8(6), 18-26. doi: 10.9790/5933-0806021826.

32. Utami, N. W. (2020). Kebijakan Fiskal Defisit. Retrieved from https://www.jurnal.id/id/blog/pengertian-kebijakan-fiskal-dantujuannya/ 